\title{
The Impact of COVID-19 Pandemic on Early Childhood Education and Comorbidities in Brazil: Challenges and Perspectives
}

\author{
Dilvani O. Santos ${ }^{1,2 *}$, Clara M. S. de Lacerda ${ }^{3}$ \\ ${ }^{1}$ Postgraduate Program in Applied Microbiology and Parasitology (PPGMPA)/Biomedical Institute, Federal Fluminense \\ University (UFF), Niterói, Brazil \\ ${ }^{2}$ Postgraduate Program in Science and Biotechnology (PPBI)/Institute of Biology, Federal Fluminense University (UFF), \\ Niterói, Brazil \\ ${ }^{3}$ Postgraduate Program in Architecture and Urbanism/Federal Fluminense University (UFF), Niterói, Brazil \\ Email: *profa.dilvani.uff@gmail.com, ${ }^{*}$ santosdilvani@gmail.com
}

How to cite this paper: Santos, D. O., \& de Lacerda, C. M. S. (2020). The Impact of COVID-19 Pandemic on Early Childhood Education and Comorbidities in Brazil: Challenges and Perspectives. Creative Education, 11, 1947-1961.

https://doi.org/10.4236/ce.2020.1110142

Received: September 10, 2020

Accepted: October 17, 2020

Published: October 20, 2020

Copyright (c) 2020 by author(s) and Scientific Research Publishing Inc. This work is licensed under the Creative Commons Attribution International License (CC BY 4.0).

http://creativecommons.org/licenses/by/4.0/

\section{Open Access}

\begin{abstract}
The COVID-19 pandemic caused numerous changes in the lives of individuals in all geographic regions, not only because of the speed of transmission, but also because the world is experiencing the fourth industrial revolution, which increases the fluxes of data and materials throughout the network society. There is a global picture of changes over time, where pandemics have been gradually replaced by chronic diseases. And, in this context, the most drastic changes in health-disease patterns occur in children and young women and are associated with the demographic and socioeconomic fluctuations that underpin the modernization complex. The current pandemic offers an opportunity for reflection on the concept of health in the current and globalized world. It is up to the human being to definitely learn. In the early childhood education, during this period of the COVID 19 pandemic, it is necessary to deal with some special issues, in a short time: 1) the migration from onsite to remote teaching in the educational system; 2) to consider the current pandemic as a state of exception without forgetting the co-existence of other morbidities that had already been hardly affecting children over the years, such as obesity, high blood pressure and diabetes and 3) the urgent need on how to manage the time for education professionals to re-invent the teaching-learning process through digital tools. Once these challenges are reached, the maintenance of the health-education binomial will have great chances of being successful through joint actions both at the governmental level and by professionals in the area of education and the family of children.
\end{abstract}




\section{Keywords}

COVID-19, Early Childhood Education, Comorbidities, Digital Tools, Global Social Inequality

\section{General Introduction}

As soon as the pandemic arrived in Brazil and, shortly afterwards, the quarantine, as one of the main control measures of COVID-19, impacted family's daily lives at all levels. Apart from that, we believe parents in general are showing signs of despair. This might be due to the lack of basic knowledge in Health Education. Then we started wondering how the children's mind would be dealing with all the news in their everyday lives? What would they think about the effects of the pandemic on their daily activities? Mainly, due to the fact that, initially, the first information about COVID-19 was that it was a disease that affected the elderly and spared children. As such, this information had a great impact on children's minds: they were being spared a completely new disease, but at the same time, adults said they had to distance themselves from the elderly (grandparents and others), as they could transmit COVID-19 to them. This information was apparently contradictory to a child's understanding. Then came other precautions related to the protection of individual and collective health and, with them, the information that the virus died with soap and water and the importance of hand washing. The child, had to process this information, but at the same time, we believe it might have been very strange to them: a virus that dies with soap and water, but that kills many people?! These reflections inspired me to create a children's story entitled "Corona: this virus wears a crown, but it is not a king!”- production of a multilingual children's book (Portuguese, English and French) to foster a better understanding on the pandemic, in a playful way for children (Santos, 2020

http://www.perse.com.br/ebook/N1595961187222/ebook.pdf). This book had an excellent repercussion around the world, once it dealt with the basics of Health Education specifically to the prevention of COVID-19. The book also intended to address other pathologies in a subtle way (tuberculosis, leprosy, chicken pox, dengue, rubella and polio), as well as the importance of vaccination as a health promotion measure and other relevant issues seen as a possible origins of SARS COV 2 and anthropocentrism.

The moment when the pandemic hit the Brazilian social context coincided with the moment when children had been back to school after a long summer vacation. In this circumstance, everything stopped in Brazil, exactly, as it had happened in other parts of the world, where the pandemic had already started, including the interruption of school classes. It was the beginning of quarantine as a measure of social protection.

The COVID-19 pandemic caused numerous changes in the lives of individuals 
in all geographic regions, because of its speed of transmission, in an intensively globalized world. It is important to notice that on December 31, 2019, the World Health Organization (WHO) was first notified of cases of pneumonia in the city of Wuhan, China. At this time, it was suspected of being caused by a new coronavirus strain. Afterwards, Chinese authorities confirmed that it was a new type of virus and was called SARS-CoV-2.

On January 30, 2020, WHO launched an international public health emergency alert due to the speed with which the virus spread across continents. On March 11, the situation was officially classified as a pandemic, although it was already present on almost all continents in February (WHO, 2020, https://www.who.int/docs/default-source/coronaviruse/situation-reports/202006 23-covid-19-sitrep-155.pdf?sfvrsn=ca01ebe_2).

The COVID-19 pandemic victims numbers were (and still are) increasingly alarming in a global scale. Behind these numbers, several historical and social aspects which were underestimated and neglected in the pre-pandemic period, have been, suddenly, unmasked. In Brazil, the law number 13.979 (February 6, 2020), provides for measures to address the public health emergency of international importance resulting from the coronavirus responsible for the 2019 outbreak. (http://www.planalto.gov.br/ccivil 03/ ato2019-2022/2020/lei/L13979compilado .htm).

In the early childhood education, during this period of the COVID 19 pandemic, it is necessary to deal with the following issues, in a short time: 1) the migration from onsite to remote teaching in the educational system maintaining the activities related to Education as a whole; 2) consider the current pandemic as a state of exception without forgetting the co-existence of other morbidities such as pathologies that had already been hardly affecting children over the years, such as obesity, high blood pressure and diabetes; 3 ) to consider that Covid-19 exposed global social inequality and the fact that not all individuals have access to digital technologies, although we live in a network (global) society and 4) the urgent need of how to manage the time for education professionals to re-invent digital tools.

This paper briefly outlines the recent reports in the context of overcoming the challenge of early childhood education in the pandemic period; discusses the impact of the pandemic on children comorbidities and the global social inequality exposition as well. The approaches on the need of re-invention of digital tools by the education professionals are also mentioned. In this current moment, Brazilian context shows that people are still partially in quarantine, and, as we see it, all the school's activities should be moved to the digital environment during the pandemic, including physical activities on line. Besides, especially in Brazil, school lunch supply by the public school could be maintained as a delivery service when possible.

On the other hand, in social realities where it's possible to develop activities outside the house, we believe it would be healthier for children to have their 
classes on open air (in the schoolyard; at urban parks and other similar locations). This would be possible in countries or regions with proved high security level attending to the WHO recommendations, where COVID-19 would not be a threat for the health of both school staff and the students as well.

\section{The Challenge of Early Childhood Education in the Pandemic Period: The Migration from Onsite to Remote Teaching in the Educational System}

Worldwide, 9 out of 10 students are temporarily out of school in response to the new coronavirus pandemic, according to data from the United Nations (UN). In Brazil, many educational institutions have already suspended classes and are making use of digital learning resources solutions, such as Distance Education (DE) modality and distance learning strategies, according to government legislation that provides for Provisional Measure No. 934 (April 1, 2020) which establishes exceptional rules for the school year of basic and higher education resulting from measures to cope with the public health emergency situation (https://www.in.gov.br/en/web/dou/-/medida-provisoria-n-934-de-1-de-abril-de -2020-250710591). But it is important to remark that these technologies and educational strategies have its limitations and it might not serve all Brazilian children and young people in the same way. However, this will be covered in depth, below, in the item 4.

Distance learning is not synonymous with online classes (Santos, Torres Júnior, \& Lacerda, 2019). There are different ways to stimulate learning remotely and, if well structured, educational activities can fulfil more than a purely academic function. Online class platforms-with videos, presentations and reading materials-should not be seen as the only means of offering remote education. It is possible and fundamental to diversify students' learning experiences. The diversity of supports and methods can support the creation of a positive routine for children and young people, ensuring some stability in the face of so many changes.

Early childhood education is one of the stages with the greatest difficulty in adapting to remote work. The pedagogical activities in this teaching stage are based on games and interactions. The variety of materials, objects, explorations, games and make-believe situations enhances the development of the little ones in different aspects, such as cognitive, affective, motor and biological. "Playfulness favours the pleasurable discovery of new knowledge, facilitates the establishment of new connections. Expands the hypotheses created by children from experimentation, spontaneous and exploratory manipulation of objects, heightens curiosity for understanding more complex concepts of nature. With the migration from face-to-face to remote education, children's routines changed abruptly. Classes started to be taught by means of distance tools, tasks organized by virtual learning environments and the systematization of the entire process started to be assisted by their families. It is up to the school community the ef- 
fective guidance in organizing students' study time at home, with the awareness that it is not the role of the family to teach and that it is necessary to invest in study routines and schedules that are feasible for this new reality. And, all this dialogue between school and family is essential in order to support the student without compromising their development and learning.

However, it is worth highlighting the impact of the pandemic on the daily lives of mothers whose school-age children need support at home for distance learning offered by schools. In fact, working parents had to create time to manage both situations: educating their children at home and their responsibilities at work. In particular, women have been terribly affected by these changes. Most of the time, they need to give up their careers to take care of their children. Unfortunately, in a patriarchal society like Brazil, domestic activities are culturally linked to women. And for these reasons, they are on the verge of emotional, physical and mental stress.

In remote education in early childhood, the proposal for educational activities to be carried out at home, it is essential that teachers consider the reality of the families. Not every family has computers or even high quality internet to follow live classes. The important thing in this case is to work with the imagination. The house should be seen as a resource, as it is rich in elements that can be used in games. With imagination it is possible to transform any object and material into play territory. The proposed activities should be designed according to the materials that the children can have at home, such as cardboard boxes, simple toys, recyclable materials, objects and common furniture at home. Children learn anywhere. To stimulate learning is to listen to children, enter their games and questions, bring points of view and problematize.

The organization of storytelling activities is an excellent learning model for children. It is possible to improvise situations using objects such as a flashlight and fabrics to create a shadow theatre. Ordinary and comic books can be used to guide storytelling. The activity helps to stimulate children's creativity and capacity for abstraction, in addition to strengthening the bonds between parents and children. Drawing activities can also be done at home, with few resources. Sheets of paper, or even a cardboard box can serve as a support. Free drawings on a specific theme help children to express ideas, desires and feelings about their experiences.

The activity of playing games such as bingo, stick-sticks, dominoes or memory games can also be used as a strategy for learning in early childhood education. Ask parents and guardians to help their children create a card with six or nine spaces, just like a real bingo card, and a card with numbers from 1 to 100 . The card can be made with a sheet of paper or other materials, like cardboard. The activities will help children to read, write and identify numbers and words.

Equally important, the online practice of physical activities under the guidance of a teacher could also be a relevant suggestion, in order to reduce children's sedentary lifestyle, bringing health benefits, in addition to mimicking the 
school environment into children's home.

To analyse a foreign example of the successful use of creativity during pandemic times, it is relevant to cite the Minnesota case in the United States. In the context of trying to minimize the impact of the pandemic on the early childhood education, many schools in Minessota districts (USA) were set to begin hybrid or distance learning procedures (Chapman, 2020)

(https://minnesota.cbslocal.com/2020/09/07/twin-cities-teacher-makes-video-toease-hybrid-distance-learning-worries/).

The collaboration between a teacher and a parent helped an entire school go back to learning in person, during this period. Despite the worries concerning the number of kids to attend the hybrid model of education, the "Prairie Creek Community School" spent the entire summer organizing themselves for different scenarios and making sure that the school was ready to step and go. The solution came with one of the parents at the school, owner of Eastvold Furniture. He proposed for a design that could be both a portable desk and a stool for outdoor learning. And, in this way, the hybrid model of education became available.

In sum, COVID-19 has changed the way to teach specially the children and, this new way of learning is also changing work habits for parents to make sure they can take part in this new venture (Raddatz, 2020)

(https://minnesota.cbslocal.com/2020/09/14/northfield-teacher-and-parent-creat e-portable-desks-for-hybrid-learning/).

\section{The Relevance of Conquering Measures to Combat Childhood Diseases Such as Obesity, Hypertension and Diabetes, in the Pre-Pandemic Period}

The COVID-19 pandemic ended up masking other challenges the world was already experiencing, such as the challenge of childhood obesity, which was already comparable to the challenge of global warming, both for its complexity and for involving several factors and issues: government, scientific community, parents and society as a whole. Childhood obesity is a condition in which excess body fat negatively affects a child's health or well-being (Reilly \& Kelly, 2011). Childhood obesity is, according to the World Health Organization (WHO), one of the most serious health problems of the $21^{\text {st }}$ century. In 2010, there were 42 million overweight children worldwide, 35 million of whom lived in developing countries, due to a number of factors such as lack of proper nutrition, physical activity, as well as biological, behavioural and psychological factors. This is not just an aesthetic problem. In addition to being frequently bullied by peers, obese children can become obese adults with a tendency to have obese children and also with serious health problems such as diabetes, heart disease and hypertension. It is worth considering that the treatment of these comorbidities in children is preferably non-pharmacological.

The WHO understands that obesity has become an epidemic (Global Strategy on Diet, Physical Activity and Health; Childhood overweight and obesity. 
http://www.who.int/dietphysicalactivity/childhood/en/). And, it is worth considering that in the last two decades (beginning of the $21^{\text {st }}$ century), several efforts have been made to prevent/control the obesity epidemic: Education for the acquisition of new eating habits as well as the regularity of physical activity were and continue to be essential for preventing obesity and its consequences (diabetes, high blood pressure and cardiomyopathies). In this context, during the last decade, the abolition of habits considered sedentary, such as the many hours spent by children in front of smartphones and computer screens, were intensively discussed on educational environments, not only to improve children's physical health, but to improve school performance (Della Barba, 2015) (http://www.bbc.com/portuguese/noticias/2015/08/150826 obesidade infantil $\underline{m d b})$. In this context, some schools in different geographical regions of the world have invested in improving their architecture, with the aim of stimulating the mobility of children in the school space, as a means of stimulating daily physical activity, outside the classroom space, where children spend most of their time, seated, in academic activity (Healy et al., 2015). According to Wilmot et al. (2012) and Thorp et al. (2011), high levels of sedentary time or, too much sitting have been linked detrimentally with cardiovascular disease, diabetes, and premature mortality. In modern society, individuals are highly sedentary, with the average self-reported sitting time ranging from 3.2 to $6.8 \mathrm{~h} /$ day across European countries (Bennie et al. 2013; Thorp et al., 2011) and objective measures indicating $55 \%-69 \%$ of adults' waking hours are spent sedentary (Matthews et al., 2008; Colley et al., 2011).

Accordingly, broadly stated guidelines on reducing sitting time have emerged. For these to become more specific guides to action, it is important to understand the relative benefits of the common daily activities (standing and stepping) that could replace sitting (Alkhajah et al., 2012). Furthermore, the literature also mentions models proposed to stimulate the child's mobility in the school space and its relevance in the socialization process-the mediation functions of the schools (Coste \& Cavalli, 2015)

(https://rm.coe.int/education-mobility-otherness-the-mediation-functions-of-sc hools/16807367ee).

It is worth mentioning that in Brazil, the public school, besides offering education, also offers school lunches, since for many poor Brazilian children, school lunches are the only meal they have per day. Thus, it would be really good if the public school could offer school lunches to children in their homes in the quarantine period. This measure would bring immense benefits to children's health, especially for children who have comorbidities such as obesity, high blood pressure and diabetes. It is worth stressing that the online practice of physical activities can help in fighting sedentary lifestyle as previously mentioned.

\section{The Impact of the Pandemic on the Global Social Inequality Exposition}

The current pandemic shows the different impacts of COVID-19 on social spheres, 
especially in the most impoverished groups. Capital worldization generates even more poverty, and the authors recognize this from different theoretical perspectives. The differences in wealth between classes or individuals are reflected in health indicators, revealing greater severity, above all, of certain infectious diseases (Souza, 2020).

The environment in which the human population lives affects their quality of life, which, in turn, depends, fundamentally, on some essential aspects such as healthy food, basic sanitation and decent housing. Without these essential living conditions, the environment in which you live affects your behaviour and, consequently, your physical and mental health. Thus, the COVID-19 pandemic exposed social inequality in some geographic regions worldwide, especially Brazil, which despite being the ninth largest economy in the world, occupies the seventh position in the question of social inequality, according to the World Health Organization (WHO)

https://www.br.undp.org/content/brazil/pt/home/presscenter/articles/2019/cond icoes-de-partida-podem-determinar-desigualdades-no-futuro--r.html).

The adoption of quarantine as a protective measure to contain the pandemic, essential to control the spread of COVID-19 was crucial, but, for the another hand, in Brazil, peripheral areas and slums became more vulnerable to the pandemic, due to the fact that individuals which live in these spaces, for being malnourished, immunologically deficient, living in agglomerated cubicles, without basic sanitation, without soap and water became more vulnerable to pandemic (Souza, 2020).

Talking, briefly, about the relevance of spaces in the quality of live of people, it is known that some environments harbour more pathogens than others and population densities vary across environment, which influences disease transmission dynamics. Moreover, variation in resource distribution across environments can determine movement patterns, which can expose individuals to new pathogens, but also contribute to their health by increasing activity. The built environment can be modified to promote healthy behaviours and reduce the risk of contracting a disease (Pinter-Wollman et al., 2018). As reviewed by PinterWollman et al., 2018, the illustration of how the built environment can affect both health behaviour and disease comes from the history of urban planning over the past century. According to these authors, the disease was the main argumentation for the advent of urban planning in Europe and the USA. Throughout the nineteenth and early twentieth century, urban environments such as London, Paris, New York City and Chicago were densely populated and characterized by residences in proximity to factories, animal yards, slaughter houses and crowded tenement houses with little airflow or light. Consequently, the cities were plagued with epidemics of infectious disease, such as cholera, tuberculosis and typhoid swept through these cities. However, according to PinterWollman et al., 2018, at that time, it was thought that congestion, pollution, lack of sun and poor airflow contributed to the disease. And so, public health move- 
ments emerged in the middle of the $19^{\text {th }}$ century and the extensive reconstruction of European and North American cities followed, with the aim of improving the conditions of overcrowded and unhealthy urban life. Zoning, that is, the separation of uses, was introduced to spatially separate residential, commercial and industrial uses, and housing regulations required light and airflow. On the other hand, according to Pinter-Wollman et al., 2018, these efforts to configure an environment built to control infectious diseases in the late 1800s and early 1900 s ended up contributing to the emergence of chronic diseases in the $21^{\text {st }}$ century, with the advent of the automobile, led, 100 years later, to environments that discourage walking and promote movement in the private automobile. We now have a physically inactive population with rising rates of obesity and related chronic diseases such as diabetes, cancer and coronary heart. Besides, as reviewed by Pinter-Wollman et al., 2018, the relationship between mental health and the built environment, in particular in urban centres, became an equally important concern. Other chronic diseases, such as depression, have also been examples of diseases associated with social and physical aspects of the built environment-from factors such as social isolation and poverty.

In sum, chronic diseases are defined as non-communicable diseases that persist for a long time and that cannot be prevented by vaccination or cured by medication alone. In contrast, infectious diseases are caused by pathogenic microorganisms and can spread among individuals. Measures to control infectious diseases include prophylactic measures such as hand washing, wearing masks for face protection and vaccination. However, in the case of chronic diseases, health promotion basically depends on changes in lifestyle and healthy eating habits. However, when it comes to the need for quarantine measures to prevent transmissible infections, one must also think about improving environmental conditions so as not to activate or re-activate the emergence of chronic diseases, which in turn, can lead to aggravation of a disease like COVID -19. And, in the specific case of children, it is necessary to reinforce the importance of food, since they are in the development phase and need healthy nutrition.

\section{The Need of Re-Invention of Digital Tools by the Education Professionals}

Creative environments for learning in schools is very important and may support creative skills development in children and young people, as reviewed by Davies et al. (2013). According to these authors, factors such as flexible use of space and time; availability of appropriate materials; working outside the classroom/school; "playful" or "games-bases" approaches with a degree of learner autonomy; respectful relationships between teachers and learners; opportunities for peer collaboration; partnerships with outside agencies; awareness of learners' needs; and nonprescriptive planning are extremely important for the success of education. Furthermore, this review also found evidence for impact of creative environments on pupil attainment and the development of teacher professional- 
ism (Davies et al., 2013).

Thus, even at a distance, teachers' performance is central. When it comes to distance learning, the work of teachers has a significant role in ensuring a good experience, regardless of the solution used. For this reason, given the current scenario, in which they are equally impacted by the pandemic, supporting them, personally and professionally, is an absolutely essential measure. Therefore, Figure 1 summarizes the challenges of early childhood education during and after the pandemic.

However, another issue to be considered here, is that Brazil occupies the $26^{\text {th }}$ position in the ranking of easiest remote work among 30 countries, which means that the country's environment does not favor the transition to remote work as it could and would deserve adjustments. In this context, Brazilian homes have some characteristics that make working at home more difficult. Almost half of them $(47 \%)$ have children under the age of 15 , which can distract adults from work. And both internet access (only $67 \%$ of the population has it) and speed (the average is $24 \mathrm{mbps}$, well below the average in the developed world) leaves much to be desired. These domestic disadvantages outweigh the advantages related to occupations that require physical proximity and, in our combined index, lead to the low overall classification of Brazil. All of the aspects discussed above apply both to remote teaching in the home of the education professional as well as in the home of the students. In short, the lockdowns and quarantines around the world, on account of COVID-19, revealed that some people work better at home and others do not-either because of their profession, domestic circumstances or other factors. And what is true for individuals is also true for regions and countries: some countries are in a better position than others to succeed while complying with social distance (Bana, Benzell, \& Solares, 2020)

https://www.mitsloanreview.com.br/post/como-os-paises-vem-se-adaptando-ao -trabalho-remoto).

In the global context, at least a third of the world's schoolchildren-463 million children globally-were unable to access remote learning when COVID-19 shuttered their schools, according to a new UNICEF report as countries across the world grapple with their "back-to-school" plans. According to Henrietta Fore, UNICEF Executive Director: "For at least 463 million children whose schools closed due to COVID-19, there was no such a thing as remote learning" and "The sheer number of children whose education was completely disrupted for months on end is a global education emergency. The repercussions could be felt in economies and societies for decades to come." (COVID-19: At least a third of the world's schoolchildren unable to access remote learning during school closures, new report say.

https://www.unicef.org/press-releases/covid-19-least-third-worlds-schoolchildre n-unable-access-remote-learning-during). At the height of nationwide and local lockdowns, around 1.5 billion schoolchildren were affected by school closures. The UNICEF report outlines the limitations of remote learning and exposes deep inequalities in access (The state of the world's children 2019. Children, food and nutrition. Growing well in a changing world.

https://www.unicef.org/sites/default/files/2019-12/SOWC-2019.pdf). 
Covid -19 pandemic : challenges on early childhood education during and after pandemic

Emotional impact on students and education professionals;

The urgent need on acquiring experience on how to use digital technologies in the online and onsite classroom;

The management of digital platforms;

Gradual return with health protection care;

Compliance with the workload required by law: balancing work time and digital tecnologies;

Frequent assessment and learning recovery;

Frequent communication with parents and guardians;

Strengthening the family-school relationship;

Technology as a continuous ally, but without underestimating the importance of healthy life habits such as: the importance of physical activity, healthy eating and face-to-face socialization (as far as possible), as ways of maintaining quality of life.

Figure 1. COVID-19 pandemic: challenges on early childhood education during and after pandemic.

\section{Conclusion}

In the history of pandemics, undoubtedly the urbanization process led to the appearance of pandemics (Pinter-Wollman et al., 2018). In the current moment, climate change, global warming, beyond question, contributed to the emergence of COVID-19 (Scientific American June 2020 pages 24-44,

https://drive.google.com/file/d/13qnXzy0bVLm5p2s/3V5AS1i-E-veLwFh/view) and, naturally will propitiate pandemics in the near future. In this pandemic scenario, there is a part of the world population that is drastically affected in every way-the children. Most of them, seems to have been spared symptoms and mortality by COVID-19 (COVID-19 in children and the role of school settings in COVID-19 transmission, 6 August 2020. Stockholm: ECDC; 2020

https://www.ecdc.europa.eu/sites/default/files/documents/COVID-19-schools-tr ansmission-August\%202020.pdf), but on the other hand, they have suffered the consequences of the alterations in the world like as the changings in lifestyle, family, in the educational system, in daily habits and emotional behaviour. Emphasis should be given to children from low-income families who, facing to COVID-19, were doubly affected: in the access to the right to health and in the access to the new education system. For this part of the population, which suffers from social inequality, the disparity is huge, since the world is in the fourth industrial revolution

(https://www.ukessays.com/essays/sociology/manuel-castells-theory-of-network -society.php), but they have not yet had access to the third industrial revolution marked by access to the digital world. Katzman \& Stanton (2020) reported some current barriers to successful online learning including the lack of secure broadband access in rural and underserved regions; the importance of social emotional learning in online distance education, and; the critical need for cultural education within the online curricula of distance platforms. According to these au- 
thors, many educational experts worry that distance education may increase a student's isolation.

In general, the activities of any children were abruptly interrupted by the pandemic. Children with practically "immobilized" in front of a computer or smartphone screen. The school, a well-known space for acquiring knowledge and socializing (and, for poor children, also a place for daily meals) was replaced by the virtual classroom and remote teaching. And this also impacted the lives of their parents and/or guardians. They now have to accompany children in remote education. Likewise, teachers' lives were also impacted.

The school space adds many values in the children's evolutionary process and, however efficient the technology may be, it can never replace the School, the face-to-face classes. Distance education is useful for adults for several reasons, as previously reviewed by our group (Santos et al., 2019), but it is certainly far from being suitable for early childhood education.

In this pandemic moment, childhood has to be re-invented: in the 90s, children lived fully, with mobility and freedom (childhood obesity was not an epidemic); in the 2000s, children became dependent on electronic and digital equipment (although childhood obesity has become an epidemic, health education measures directed against childhood obesity have been successful with the help of the School) and, today, in full pandemic, the world is in danger of going backwards in all directions, mainly in the aggravation of the comorbidities that affect children (Pietrobelli et al., 2020). It is noteworthy to mention that the pandemic continues, cases of re-infection have been reported, (Vella, 2020) (https://thehill.com/policy/healthcare/513564-two-european-cases-of-re-infectio n-from-coronavirus-reported; COVID-19 in children and the role of school settings in COVID-19 transmission, 6 August 2020. Stockholm: ECDC; 2020 https://www.ecdc.europa.eu/sites/default/files/documents/COVID-19-schools-tr ansmission-August\%202020.pdf) and vaccination against COVID-19 is still a hope, however, preventive measures, including social isolation, are still extremely necessary.

In view of the quarantine in Brazil, the school is not moving home, but the main elements of school educational activities must be transferred to the children's home, including measures to maintain physical activities and food. At the present time, the joint action of government, educators, parents and the children themselves is of utmost importance to minimize the undesirable effects on health and education that go far beyond COVID-19.

\section{Acknowledgements}

We thank the PostGraduate Program in Applied Microbiology and Parasitology (PPGMPA), the Postgraduate Program in Science and Biotechnology (PPBI and the PostGraduate Program in Architecture and Urbanism, from the Universidade Federal Fluminense (UFF), Niterói, RJ, Brazil for stimulating scientific development. Clara M. S. de Lacerda is a master's student in the Graduate Program 
in Architecture and Urbanism with a fellowship from the Brazilian federal government agency-CAPES (Coordenação de Aperfeiçoamento de Pessoal de Nível Superior, Brazil).

\section{Conflicts of Interest}

The authors declare no conflicts of interest regarding the publication of this paper.

\section{References}

(2018). UKEssays. (November). Manuel Castells' Theory of Network Society. https://www.ukessays.com/essays/sociology/manuel-castells-theory-of-network-society .php?vref=1

(2019). https://www.unicef.org/sites/default/files/2019-12/SOWC-2019.pdf

(2020). COVID-19 in Children and the Role of School Settings in COVID-19 Transmission. Stockholm: ECDC.

https://www.ecdc.europa.eu/sites/default/files/documents/COVID-19-schools-transmis sion-August $\% 202020$.pdf

(2020). COVID-19: At Least a Third of the World's Schoolchildren Unable to Access Remote Learning during School Closures, New Report Say.

https://www.unicef.org/press-releases/covid-19-least-third-worlds-schoolchildren-una ble-access-remote-learning-during

(2020). Law Number 13.979/Brasil. http://www.planalto.gov.br/ccivil 03/ ato2019-2022/2020/lei/L13979compilado.htm

(2020). Provisional Measure No. 934/Brasil. https://www.in.gov.br/en/web/dou/-/medida-provisoria-n-934-de-1-de-abril-de-2020$\underline{250710591}$

Alkhajah, T. A., Reeves, M. M., Eakin, E. G., Winkler, E. A., Owen, N., \& Healy, G. N. (2012). Sit-Stand Workstations: A Pilot Intervention to Reduce Office Sitting Time. American Journal of Preventive Medicine, 43, 298-303. https://doi.org/10.1016/j.amepre.2012.05.027

Bana, S. H., Benzell, G., \& Solares, R. R. (2020). Países distintos, home office distinto. https://www.mitsloanreview.com.br/post/como-os-paises-vem-se-adaptando-ao-trabal ho-remoto

Bennie, J. A., Chau, J. Y., van der Ploeg, H. P., Stamatakis, E., Do, A., \& Bauman, A. (2013). The Prevalence and Correlates of Sitting in European Adults-A Comparison of 32 Eurobarometer-Participating Countries. International Journal of Behavioral Nutrition and Physical Activity, 10, 107-115. https://doi.org/10.1186/1479-5868-10-107

Chapman, R. (2020). Twin Cities Teacher Makes Video to Ease Hybrid, Distance Learning Worries.

https://minnesota.cbslocal.com/2020/09/07/twin-cities-teacher-makes-video-to-ease-h ybrid-distance-learning-worries

Colley, R. C., Garriguet, D., Janssen, I., Craig, C. L., Clarke, J., \& Tremblay, M. S. (2011). Physical Activity of Canadian Adults: Accelerometer Results from the 2007 to $2009 \mathrm{Ca}-$ nadian Health Measures Survey. Health Reports, 22, 7-14.

Coste, D., \& Cavalli, M. (2015). Education, Mobility, Otherness the Mediation Functions of Schools.

https://rm.coe.int/education-mobility-otherness-the-mediation-functions-of-schools/1 $\underline{6807367 e e}$ 
Davies, D., Jindal-Snape, D., Collier, C., Digbya, R., Haya, P., \& Howea, A. (2013). Creative Learning Environments in Education-A Systematic Literature Review. Thinking Skills and Creativity, 8, 80-91. https://doi.org/10.1016/j.tsc.2012.07.004

Della Barba, M. (2015). Brasil pode se tornar país mais obeso do mundo em 15 anos. BBC Brasil em Londres. http://www.bbc.com/portuguese/noticias/2015/08/150826 obesidade infantil mdb

Healy, G. N., Winkler, E. A. H., Owen, N., Anuradha, S., \& Dunstan, D. W. (2015). Replacing Sitting Time with Standing or Stepping: Associations with Cardio-Metabolic Risk Biomarkers. European Heart Journal, 36, 2643-2649. https://doi.org/10.1093/eurheartj/ehv308

Katzman, N. F., \& Stanton, M. P. (2020). The Integration of Social Emotional Learning and Cultural Education into Online Distance Learning Curricula: Now Imperative during the COVID-19 Pandemic. Creative Education, 11, 1561-1571. https://doi.org/10.4236/ce.2020.119114

Matthews, C. E., Chen, K. Y., Freedson, P. S., Buchowski, M. S., Beech, B. M., Pate, R. R., \& Troiano, R. P. (2008). Amount of Time Spent in Sedentary Behaviors in the United States, 2003-2004. American Journal of Epidemiology, 167, 875-881.

https://doi.org/10.1093/aje/kwm390

Pietrobelli, A., Pecoraro, L., Ferruzzi, A., Heo, M., Faith, M., Zoller, T., Antoniazzi, F., Piacentini, G., Fearnbach, N. S., \& Heymsfield, S. B. (2020). Effects of COVID-19 Lockdown on Lifestyle Behaviors in Children with Obesity Living in Verona, Italy: A Longitudinal Study. Obesity, 28, 1382-1385. https://doi.org/10.1002/oby.22861

Pinter-Wollman, N., Jelic, A., \& Wells, N. M. (2018). The Impact of the Built Environment on Health Behaviours and Disease Transmission in Social Systems. Philosophical Transactions of the Royal Society B, 373, Article ID: 20170245. https://doi.org/10.1098/rstb.2017.0245

Raddatz, K. (2020). Northfield Teacher and Parent Create Portable Desks for Hybrid Learning. https://minnesota.cbslocal.com/2020/09/14/northfield-teacher-and-parent-create-porta ble-desks-for-hybrid-learning

Reilly, J. J., \& Kelly, J. (2011). Long-Term Impact of Overweight and Obesity in Childhood and Adolescence on Morbidity and Premature Mortality in Adulthood: Systematic Review. International Journal of Obesity, 35, 891-898.

https://doi.org/10.1038/ijo.2010.222

Santos, D. (2020). Corona: Esse vírus usa coroa, mas não é rei! Corona: This Virus Wears a Crown, But It Is Not a King! Corona: Ce virus porte une couronne, mais ce n'est pas un ro1? PerSe Ed. São Paulo, Brazil. http://www.perse.com.br/ebook/N1595961187222/ebook.pdf

Santos, D., Torres Júnior, J., \& Lacerda, C. M. S. (2019). Broadening Horizons through Distance Learning: New Challenges for Education in Brazil and Some Other Geographical Areas. Creative Education, 10, 156-162. https://doi.org/10.4236/ce.2019.101012

Scientific American June 2020 Pages 24-44. https://drive.google.com/file/d/13qnXzy0bVLm5p2s/3V5AS1i-E-veLwFh/view

Souza, D. O. (2020). The COVID-19 Pandemic beyond Health Sciences: Reflections on Its Social Determination. Ciência \& Saúde Coletiva, 25, 2469-2477. https://doi.org/10.1590/1413-81232020256.1.11532020

Thorp, A. A., Owen, N., Neuhaus, M., \& Dunstan, D. W. (2011). Sedentary Behaviors and Subsequent Health Outcomes in Adults a Systematic Review of Longitudinal Studies, 
1996-2011. American Journal of Preventive Medicine, 41, 207-215.

https://doi.org/10.1016/j.amepre.2011.05.004

Vella, L. (2020). Two European Cases of Coronavirus Re-Infection. https://thehill.com/policy/healthcare/513564-two-european-cases-of-re-infection-from -coronavirus-reported

WHO (2020).

https://www.who.int/docs/default-source/coronaviruse/situation-reports/20200623-cov id-19-sitrep-155.pdf?sfvrsn=ca01ebe 2

Wilmot, E. G., Edwardson, C. L., Achana, F. A., Davies, M. J., Gorely, T., Gray, L. J., Khunti, K., Yates, T., \& Biddle, S. J. (2012). Sedentary Time in Adults and the Association with Diabetes, Cardiovascular Disease and Death: Systematic Review and $\mathrm{Me}-$ ta-Analysis. Diabetologia, 55, 2895-2905. https://doi.org/10.1007/s00125-012-2677-z

World Health Organization (WHO) (n.d.). Global Strategy on Diet, Physical Activity and Health; Childhood Overweight and Obesity.

https://www.who.int/dietphysicalactivity/childhood/en/

World Health Organization (WHO).

https://www.br.undp.org/content/brazil/pt/home/presscenter/articles/2019/condicoesde-partida-podem-determinar-desigualdades-no-futuro--r.html 